\title{
Where should we start to improve pediatric heart transplantation outcomes?
}

Jinyoung Song, MD, PhD

Department of Pediatrics, Samsung Medical Center, Sungkyunkwan University School of Medicine, Korea

\begin{abstract}
Key message
- Pediatric heart transplantation is achieving better outcomes.

- The waitlist mortality is still high, especially in Korea, and should be reduced.

The use of ventricular assist device is promising and might offer improved waitlist mortality rates.
\end{abstract}

The current era has seen a marked increase in pediatric heart transplantation success and survival rates despite variety in recipient heart disease and more limited resources in pediatric patients. Advances in surgical techniques, immunosuppressant treatment after transplantation, and the early detection of graft failure contribute to this improvement. $\mathrm{Kim}^{1)}$ recently reviewed issues that affect long-term outcomes such as immunosuppression and the surveillance of graft rejection. Considering the severe limitations of suitable donor hearts, the first step towards achieving optimal outcomes involves reducing waitlist mortality rates.

Pediatric waitlist mortality rates are 5\%-30\% and vary among countries, regions, and institutions. ${ }^{2-4)}$ Significant risk factors for such mortality include the use of extracorporeal membrane oxygenation (ECMO) or ventilator support, congenital heart disease (CHD), patient weight less than $3 \mathrm{~kg}$, non-White race, United Network of Organ Sharing status of $1 \mathrm{~A}$, and need for dialysis. $^{5,6)}$ However, there has been a significant decrease in waitlist mortality rates with changes in donor allocations and the use of ventricle assist devices (VADs) as a bridge to transplantation. ${ }^{7,8)}$ The latter resulted in a large decrease in waitlist mortality

Table 1. Data of patients who died while being waitlisted

\begin{tabular}{lc}
\hline Variable & Value \\
\hline No. of patients & 15 \\
Age of registation $(y r)$ & $3.2(0.0-15.3)$ \\
Time to death from registration (day) & $142(7-1,409)$ \\
Mechanical circulatory support & $9(60.0)$ \\
Congenital heart diseaes & $4(26.7)$ \\
\hline
\end{tabular}

Values are presented as median (range) or number (\%). rates as well as increased posttransplantation survival rates than by bridging with ECMO.

The analysis of preliminary data in our institute until December 2019 (Table 1) revealed a 40.5\% waitlist mortality rate. Mechanical circulatory support (MCS) was used in 9 patients (60.0\%), and the main MCS was ECMO since true pediatric VAD was not available at that time in Korea. Mean age at trans. plantation registration and mean time to death after registration did not differ between patients with MCS and those without MCS (3.2 years vs. 2.2 years and 142.0 days vs. 153.5 days, $P>0.05)$. The mean MCS duration was 48 days, and most causes of mortality in our patients were related with MCS. We were unable to prove that ECMO use was related with higher waitlist mortality rates than was VAD use due to the small number of patients.

Complex CHD that cannot be treated is more risky than various forms of pediatric cardiomyopathy. Patients with complex CHD are generally at higher risk of an increased rate of histocompatibility antigen sensitization. Researchers have sug. gested antibody depletion and use of the first suitable donor heart regardless of cross-match results for highly sensitized patients. ${ }^{9)}$ ABO-incompatible donor heart transplantation has been performed, especially in young infants, and showed good results. ${ }^{10)} \mathrm{ABO}$-incompatible heart transplantation has been standard among children up to 2 years of age in the United States. There are no uniform criteria of a favorable donor heart for pediatric heart transplantation, and the decision of suitability remains subjective. The decision to perform transplantation has been based on donor heart function, weight ratio, and inotrope use, but extended-criteria donors are now being used in adult patients. ${ }^{11)}$ Therefore, various modifications of donor heart criteria and an increased use of marginal donor hearts can contribute to reductions in waitlist mortality rates. Long-term studies on the long-term survival of such transplants should be continued.

In adult heart transplantation, donation after circulatory death (DCD) is becoming more widely accepted and relatively more prevalent in Europe. A case report described a child who

\footnotetext{
Corresponding author: Jinyoung Song, MD, PhD. Department of Pediatrics, Samsung Medical Center, Heart Vascular Stroke Institute, Grown-up Congenital Heart Clinic, Sungkyunkwan University School of Medicine, 81 Irwon-ro, Gangnam-gu, Seoul 06351, Korea 凶Email: amyjys@naver.com, https://orcid.org/0000-0002-9660-5949

Received: 8 April, 2020, Revised: 6 May, 2020, Accepted: 7 May, 2020

This is an open-access article distributed under the terms of the Creative Commons Attribution Non-Commercial License (http://creativecommons.org/licenses/bync/4.0/) which permits unrestricted non-commercial use, distribution, and reproduction in any medium, provided the original work is properly cited. Copyright (c) 2020 by The Korean Pediatric Society
} 
underwent successful heart transplantation of DCD. ${ }^{12)}$ Although more studies are needed, great advances in pediatric heart transplantation could be achieved with DCD in the future.

In conclusion, efforts to minimize waitlist mortality should consistently aim to not compromise long-term outcomes.

\section{Conflicts of interest}

No potential conflict of interest relevant to this article was reported.

See the article "Pediatric heart transplantation: How to manage problems affecting long-term outcomes?" via https:/doi. org/10.3345/cep.2019.01417.

\section{References}

1. Kim YH. Pediatric heart transplantation: how to manage problems affecting long-term outcomes? Clin Exp Pediatr 2020 Aug 8 [Epub]. https://doi.org/10.3345/cep.2019.01417.

2. Shimizu M, Nishinaka T, Inai K, Nakanishi T. Outcomes in children with advanced heart failure in Japan: importance of mechanical circulatory support. Heart Vessels 2016;31:1162-7.

3. Smits JM, Thul J, De Pauw M, Delmo Walter E, Strelniece A, Green D, et al. Pediatric heart allocation and transplantation in Eurotransplant. Transpl Int 2014;27:917-25.

4. Rana A, Fraser CD, Scully BB, Heinle JS, McKenzie ED, Dreyer WJ, et al. Inferior outcomes on the waiting list in low-volume pediatric heart transplant centers. Am J Transplant 2017;17:1515-24.
5. Mah D, Singh TP, Thiagarajan RR, Gauvreau K, Piercey GE, Blume ED, et al. Incidence and risk factors for mortality in infants awaiting heart transplantation in the USA. J Heart Lung Transplant 2009;28:1292-8.

6. Almond CSD, Thiagarajan RR, Piercey GE, Gauvreau K, Blume ED, Bastardi HJ, et al. Waiting list mortality among children listed for heart transplantation in the United States. Circulation 2009;119:717-27.

7. Jeewa A, Manlhiot C, Kantor PF, Mital S, McCrindle BW, Dipchand AI. Risk factors for mortality or delisting of patients from the pediatric heart transplant waiting list. J Thorac Cardiovasc Surg 2014;147:462-8.

8. Zafar F, Castleberry C, Khan MS, Mehta V, Bryant R 3rd, Lorts A, et al. Pediatric heart transplant waiting list mortality in the era of ventricular assist devices. J Heart Lung Transplant 2015;34:82-8.

9. Daly KP, Chandler SF, Almond CS, Singh TP, Mah H, Milford E, et al. Antibody depletion for the treatment of crossmatch-positive pediatric heart transplant recipients. Pediatr Transplant 2013;17:661-9.

10. Henderson HT, Canter CE, Mahle WT, Dipchand AI, LaPorte K, Schechtman KB, et al. ABO-incompatible heart transplantation: analysis of the Pediatric Heart Transplant Study (PHTS) database. J Heart Lung Transplant 2012;31:173-9.

11. Zaroff JG, Rosengard BR, Armstrong WF, Babcock WD, D'Alessandro A, Dec GW, et al. Consensus conference report: maximizing use of organs recovered from the cadaver donor: cardiac recommendations, March 2829, 2001, Crystal City, Va. Circulation 2002;106:836-41.

12. Khushnood A, Butt TA, Jungschleger J, Henderson P, Smith JH, De Rita F, et al. Paediatric donation after circulatory determined death heart transplantation using donor normothermic regional perfusion and ex situ heart perfusion: a case report. Pediatr Transplant 2019;23:e13536.

How to cite this article: Song J. Where should we start to improve outcomes of pediatric heart transplantation? Clin Exp Pediatr 2021;64:76-7. https://doi.org/10.3345/cep.2020.00584 